\title{
Hubungan Pola Makan, Tingkat Kecukupan Energi, dan Protein dengan Status Gizi pada Remaja
}

\section{Relationship between Eating Pattern, Energy and Protein Adequacy Level with Nutritional Status in Adolescent}

\author{
Harvita Damara Utami ${ }^{1}$, Kamsiah ${ }^{2}$, Afriyana Siregar ${ }^{3}$ \\ Program Studi Gizi, Politeknik Kesehatan Kemenkes Bengkulu, Indonesia
}

\section{ARTICLE INFO}

\section{Article history}

Received date

25 August 2020

Revised date

27 August 2020

03 Sept 2020

Accepted date

23 Sept 2020

Keywords:

Adequacy level;

Diet;

Energy and protein

nutrition status.

\section{Kata kunci:}

Pola makan; Status Gizi;

Tingkat kecukupan energi dan protein.

\author{
ABSTRACT/ ABSTRAK
}

\begin{abstract}
Adolescence is a time of growth and development. The process of growth and development takes place quickly so that the level of adequate protein and energy increases. Diet is an important habit that can affect nutritional status and meet nutritional needs. The research objective was to determine the relationship between diet, energy, and protein adequacy levels with adolescent nutritional status. The research design used analytic observational with the cross sectional approach. The population of all respondents aged 12-16 years at SMP IT Iqra consisting of 491 people with 88 people as the sample, using stratification random sampling technique. Data collection used primary data with the FFQ form and Food Recall for nutritional status using scales and microtoise. Data processing is carried out in several steps, editing, coding, tabulating, entry, and cleaning. Data analysis was univariate and bivariate with the Chi-square test. The results showed that there was a relationship between diet, energy adequacy level, and protein adequacy level with adolescent nutritional status. In conclusion, there is a significant relationship between diet, energy adequacy level, and protein adequacy level with adolescent nutritional status. It is better if schools conduct education about good eating patterns and eating portions by the guidelines for balanced nutrition to the Teens of SMP IT Iqra Bengkulu City so that their normal nutritional status increases.
\end{abstract}

Masa remaja adalah waktu pertumbuhan dan perkembangan. Proses tumbuh kembang berlangsung cepat sehingga tingkat kecukupan protein dan energi meningkat. Pola makan merupakan kebiasaan penting yang dapat mempengaruhi status gizi dan memenuhi kebutuhan gizi. Tujuan penelitian untuk mengetahui hubungan pola makan, tingkat kecukupan energi dan protein dengan status gizi remaja. Desain penelitian menggunakan observasional analitik dengan pendekatan cross sectional. Populasi seluruh responden usia 12-16 tahun yang ada di SMP IT Iqra yang terdiri dari 491 orang dengan 88 orang sebagai sampel, menggunakan teknik stratifikasi random sampling. Pengumpulan data menggunakan data primer dengan form FFQ dan Food Recall untuk Status gizi mengggunkan timbangan dan microtoise. Pengolahan data dilakukan beberapa tahap, editing, coding, tabulating, entry dan cleaning. Analisis data secara univariat dan bivariat dengan uji Chi-square. Hasil penelitian menunjukan ada hubungan pola makan, tingkat kecukupan energi, dan tingkat kecukupan protein dengan status gizi remaja. Kesimpulan ada hubungan yang bermakna antara pola makan, tingkat kecukupan energi, dan tingkat kecukupan protein dengan status gizi remaja. Sebaiknya sekolah melakukan edukasi tentang pola makan yang baik dan porsi makan sesuai dengan pedoman gizi seimbang kepada Remaja SMP IT Iqra Kota Bengkulu agar status gizi normal meningkat.

\section{Corresponding Author:}

Harvita Damara Utami

Program Studi Diploma III Gizi, Politeknik Kesehatan Kemenkes Bengkulu, Indonesia

Email: harvitadamara@gmail.com

PENDAHULUAN
Kebutuhan gizi remaja relatif besar karena remaja masih mengalami pertumbuhan dan umumnya melakukan aktivitas fisik lebih tinggi dibandingkan 
usia lainnya, sehingga diperlukan zat gizi yang lebih banyak (Adriani dan Wijatmadi, 2012). Pada masa ini remaja mengalami perkembangan fisik, psikologi dan pola identifikasi dari anak-anak menjadi dewasa. Perubahan fisik ditandai dengan pertumbuhan badan yang pesat dan matangnya organ reproduksi. Perubahan-perubahan yang terjadi pada responden cenderung akan menimbulkan berbagai permasalahan dan perubahan perilaku di kehidupan responden (Proverawati A, 2009).

Rentan gizi yang terjadi pada remaja disebabkan oleh kebutuhan gizi responden yang memerlukan zat gizi lebih tinggi karena pertumbuhan fisik dan perkembangan yang meningkat, perubahan gaya hidup dan kebiasaan makan responden, dan juga responden yang aktif dalam kegiatan olahraga, menderita penyakit kronis, sedang hamil, pecandu alkohol atau obat terlarang, melakukan diet secara berlebihan untuk menurunkan atau mempertahankan berat badan sehingga mempengaruhi kebutuhan konsumsi zat gizi (Almatsier, 2014).

Adanya masalah kekurangan dan kelebihan dalam konsumsi zat gizi dapat membawa dampak bagi kesehatan yaitu masalah gizi ganda, baik masalah gizi kurang atau gizi lebih (Almatsier, 2013). Faktor penyebab langsung masalah gizi, baik masalah gizi lebih atau masalah gizi kurang adalah ketidakseimbangan antara asupan makanan dengan kebutuhan tubuh serta adanya penyakit infeksi (Achmadi, 2013).Salah satu bentuk perubahan perilaku pada masa remaja adalah perubahan pola makan, baik mengarah pola makan yang baik ataupun cenderung mengarah kepada pola makan yang tidak baik (Proverawati A, 2009).

Pola makan yang baik harusnya dibarengi dengan pola gizi seimbang, yaitu pemenuhan zat-zat gizi yang telah disesuaikan dengan kebutuhan tubuh dan diperoleh melalui makanan sehari-hari. Pola makan menunjukkan cara pemenuhan kebutuhan nutrisi bagi seseorang yang diwujudkan dalam bentuk konsumsi jenis makanan, jumlah makanan dan frekuensi makan. Bahan makanan sumber gizi seimbang tersebut dikelompokan, yaitu: sumber energi, sumber zat pembangun, dan sumber zat pengatur. Golongan bahan makanan yaitu makanan pokok, lauk protein hewani dan nabati, sayuran, dan buah (Almatsier, 2013).

Manusia membutuhkan energi untuk mempertahankan hidup guna menunjang proses pertumbuhan dan melakukan aktivitas harian. Apabila kecukupan energi yang dibutuhkan tubuh kurang akan digunakan simpanan cadangan energi yang terdapat di dalam tubuh yang disimpan dalam otot. Kekurangan asupan energi apabila berlangsung dalam jangka waktu yang lama akan mengakibatkan menurunnnya berat badan dan kukurangan zat gizi lainnya. Keadaan ini jika berkelanjutan dapat mengakibatkan menurunnya produktivitas kerja, merosotnya prestasi belajar, dan kreatifitas. Sedamgkan konsumsi energi yang melebihi kecukupan dan mengakibatkan kenaikan berat badan dan akan menyebabkan kegemukan apabila secara terus menerus (Kusuma, dkk., 2013).
Selama masa remaja, kebutuhan protein meningkat karena proses tumbuh kembang berlangsung cepat. Protein sangat dibutuhkan pada kelompok remaja karena digunakan tubuh untuk pembentukan jaringan baru atau untuk memperbaiki jaringan yang rusak. Kekurangan protein akan berdampak pada proses pertumbuhan yang kurang baik, daya tahan tubuh menurun, lebih rentan terhadap penyakit serta daya kreatifitas dan daya kerja merosot (Kartosapoetra, 2003).

Masalah kesehatan dan kekurangan konsumsi makanan akan menyebabkan terjadinya gangguan proses metabolisme tubuh mengarah pada timbulnya suatu penyakit infeksi, defresi, anemia, mudah letih dan kurang produktifitas (Adriani dan Wirjatmadi, 2012). Demikian juga sebaliknya apabila mengkonsumsi makanan berlebih, tanpa diimbangi suatu kegiatan fisik yang cukup, gangguan tubuh juga akan muncul seperti kegemukan. Kelebihan energi di dalam tubuh disimpan dalam bentuk jaringan lemak dan dapat meningkatkan prevalensi beberapa penyakit (Proverawati dan Wati, 2011).

Indonesia dihadapkan dengan masalah gizi ganda tersebut. Berdasarkan hasil Balitbangkes 2018 tentang status gizi remaja di Indonesia menunjukan prevalensi kurus pada responden berdasarkan IMT/U yaitu sebesar $13,5 \%$ kurus. Prevalensi kegemukan sebesar 20,7\% gemuk (Kementerian Kesehatan RI, 2018). Hasil Balitbangkes Provinsi Bengkulu tahun 2019 menunjukan prevalensi pada remaja berdasarkan IMT/U yaitu sebesar $10,7 \%$ kurus. Prevalensi kegemuk sebesar 20,1\% gemuk (Kementerian Kesehatan RI, 2018).

Hasil survei awal pada tanggal 14 November 2019 di SMP IT IQRA Kota Bengkulu diketahui bahwa dari 10 responden/i yang diwawancarai kemudian dinilai status gizi dengan menggunakan IMT/U menunjukan 1 responden mengalami status gizi kurus, 5 responden status gizi normal dan 4 responden mengalami status gizi lebih dengan pola makan dan tingkat kecukupan belum ada yang sesuai dengan pedoman gizi seimbang.

Berdasarkan latar belakang masalah masih adanya status gizi yang tidak normal maka perlu diteliti adanya hubungan pola makan, tingkat kecukupan energi dan protein dengan status gizi pada remaja di SMP IT Iqra Kota Bengkulu Tahun 2020.

\section{METODE}

Jenis penelitian analitik yang bersifat observasional dengan menganalisis hubungan kedua variabel yaitu variabel independen (Pola makan, tingkat kecukupan energi dan protein) dan variabel dependen (status gizi). Penelitian ini menggunakan desain potong lintang (cross sectional) yaitu pengukuran variabel dilakukan bersamaan dan secara langsung.

Sampel yang digunakan dalam penelitian ini adalah Responden SMP IT IQRA Kota Bengkulu sebanyak 83 responden dengan teknik stratifikasi random sampling dengan cara mengidentifikasi 
karakteristik umum dari anggota populasi, dilanjutkan dengan simple random sampling. Sampel pada penelitian ini ditentukan berdasarkan pertimbangan peneliti dengan kriteria inklusi yaitu Responden yang memiliki usia 12-16 tahun, Tidak sedang menjalani diet/puasa, dan bersedia melalukan wawancara secara langsung.

Data pola makan didapatkan menggunakan formulir FFQ kemudian dilakukan pengolahan data. Proses editing dari variabel tingkat kecukupan energi dan protein yang didapatkan menggunakan formulir recall 2x24 Jam yang kemudian di konversi kedalam Nutrisurvey. Data status gizi didapatkan dengan pengukuran tinggi badan dan berat badan. Proses coding hasil dari recall 24 jam energi diberikan kode $0=$ tidak baik, jika $<100 \%$ dan $>105 \%$ dari AKG. 1=baik, jika 100-105\% dari AKG. Protein diberikan kode $0=$ tidak baik, jika $<80 \%$ dan $>100 \%$ dari AKG. 1=baik, jika $80-100 \%$ dari AKG. Hasil dari pola makan diberikan kode $0=$ tidak baik, apabila 2 kategori dari jenis, jumlah, dan frekuensi tidak terpenuhi. 1=baik apabila 2 kategori dari jenis, jumlah, dan frekuensi terpenuhi. Data dari Status Gizi diberikan kode $0=$ tidak normal, jika $>1$ SD Sampai 2SD atau 3SD sampai 2SD. 1=Normal, jika -2SD sampai 1SD. Kemudian dilakukan tabulasi data, entri data, dan Cleaning. Analisis data meliputi analisis univariat dan analisis bivariat menggunakan uji Chi-square.

Penelitian ini telah mendapatkan Keterangan Layak Etik dengan No.KEPK.M/271/04/2020 dari Komite Etik Penelitian Kesehatan Poltekkes Kemenkes Bengkulu.

\section{HASIL}

Tabel 1. Distribusi Gambaran Pola Makan, Tingkat Kecukupan Energi, Tingkat Kecukupan Protein, dan Status Gizi Responden

\begin{tabular}{lcc}
\hline \multicolumn{1}{c}{ Variabel } & n & $\%$ \\
\hline Pola Makan & & \\
\hline Tidak Baik & 55 & 62,5 \\
Baik & 33 & 37,5 \\
\hline Kecukupan Energi & & \\
\hline Tidak Baik & 65 & 73,9 \\
Baik & 23 & 26,1 \\
\hline Kecukupan Protein & & \\
\hline Tidak Baik & 47 & 53.4 \\
Baik & 41 & 46.6 \\
\hline Status Gizi & & \\
\hline Tidak Normal & 46 & 52,3 \\
Normal & 42 & 47,7 \\
\hline
\end{tabular}

Dalam tabel 1 dapat diketahui dari 88 responden, terdapat sebagian besar responden $(62,5 \%)$ memiliki pola makan tidak baik, $73,9 \%$ memiliki kecukupan energi tidak baik, 53,4\% memiliki kecukupan protein tidak baik 52,3\% memiliki status gizi tidak normal.
Tabel 2. Hubungan Pola Makan, Tingkat Kecukupan Energi, Tingkat Kecukupan Protein dengan Status Gizi Status Gizi

\begin{tabular}{|c|c|c|c|c|c|c|}
\hline \multirow{3}{*}{ Variabel } & \multicolumn{4}{|c|}{ Status Gizi } & \multirow{2}{*}{\multicolumn{2}{|c|}{ Total }} \\
\hline & \multicolumn{2}{|c|}{$\begin{array}{c}\text { Tidak } \\
\text { Normal }\end{array}$} & \multicolumn{2}{|c|}{ Normal } & & \\
\hline & $\mathbf{n}$ & $\%$ & $\mathbf{n}$ & $\%$ & $\mathbf{n}$ & $\%$ \\
\hline \multicolumn{7}{|l|}{ Pola Makan } \\
\hline Tidak Baik & 34 & 38,6 & 21 & 47,5 & 55 & 62,5 \\
\hline Baik & 12 & 13,7 & 21 & 23,8 & 33 & 37,5 \\
\hline \multicolumn{7}{|c|}{ Tingkat Kecukupan Energi } \\
\hline Tidak Baik & 39 & 44,3 & 26 & 29,6 & 65 & 73,9 \\
\hline Baik & 7 & 8 & 16 & 18,1 & 23 & 26,1 \\
\hline \multicolumn{7}{|c|}{ Tingkat Kecukupan Protein } \\
\hline Tidak Baik & 30 & 34,1 & 17 & 19,3 & 47 & 53,4 \\
\hline Baik & 16 & 18,2 & 25 & 28,4 & 41 & 46,6 \\
\hline
\end{tabular}

Berdasarkan tabel 2 dapat diketahui bahwa dari 88 responden dengan sebagian besar responden $(47,5 \%)$ memiliki pola makan tidak baik yang memiliki status gizi normal.

Diketahui pula bahwa $44,3 \%$ memiliki tingkat kecukupan energi tidak baik yang memiliki status gizi tidak normal. Hasil olah data menggunakan Chi-Square diketahui $p$ value $=0,028$, maka dapat disimpulkan bahwa ada hubungan yang bermakna antara tingkat kecukupan energi dengan status gizi responden SMP IT Iqra Kota Bengkulu Tahun 2020. Hasil analisis asosiasi (OR) responden dengan kategori kecukupan energi tidak baik berpeluang 3,4 kali lebih besar memiliki status gizi tidak normal dibandingkan dengan responden yang memiliki kecukupan energi baik.

Sebanyak $34,1 \%$ memiliki tingkat kecukupan energi tidak baik yang memiliki status gizi tidak normal. Hasil olah data menggunakan Chi-Square diketahui $p$-value $=0,035$, maka dapat disimpulkan bahwa ada hubungan yang bermakna antara tingkat kecukupan protein dengan status gizi responden SMP IT Iqra Kota Bengkulu Tahun 2020. Hasil analisis ukuran asosiasi (OR) responden dengan kategori kecukupan protein tidak baik berpeluang 2,7 lebih besar memilik status gizi tidak normal dibandingkan dengan responden yang memiliki kecukupan protein baik.

\section{PEMBAHASAN}

\section{Distribusi Pola Makan Responden}

Sebagian besar pola makan dari jenis, frekuensi dan jumlah makanan responden belum 
mencukupi atau sesuai dengan ajuran pedoman gizi seimbang. Kebanyakan responden tidak cukup jumlah atau porsi makanan. Begitu juga frekuensi makan yaitu frekuensi makan lebih dari 2-3x/hari dikategorikan tidak baik. Jika pola makan responden dari jenis, jumlah dan frekuensi makanan hanya salah satu yang tidak baik maka disimpulkan pola makan baik.

Pola makan responden yang baik dengan rata-rata kebutuhan responden sesuai dengan kebutuhan yang diajurkan dalam pedoman gizi seimbang. Kebutuhan jumlah/porsi untuk responden usia 12-15 tahun makanan pokok 4-61/2 porsi/hari, lauk hewani 2-3 porsi/hari, lauk nabati 3 porsi/hari, sayuran 3 porsi/hari, dan buah 4 porsi/hari (Kementerian Kesehatan RI, 2014).

Pola makan seimbang responden, menurut Almatsier (2011) bahwa pola makan menunjukkan cara pemenuhan kebutuhan kebutuhan nutrisi bagi seseorang yang diwujudkan dalam bentuk konsumsi jenis makanan, jumlah makanan dan frekuensi makan. Kebutuhan gizi responden relatif besar, karena responden masih mengalami masa pertumbuhan. Selain itu, responden umumnya melakukan aktivitas fisik lebih tinggi dibandingkan usia lainnya, sehingga diperlukan zat gizi yang lebih banyak (Adriani dan Wirjatmadi, 2012).

\section{Gambaran Tingkat Kecukupan Energi}

Rata-rata hasil responden memiliki tingkat kecukupan energi tidak baik dikarenakan kebutuhan responden masih belum sesuai dengan kebutuhan yang diajurkan dalam pedoman gizi seimbang. Kebutuhan energi yang dibutuhkan responden perempuan 12-15 tahun yaitu 2000$2125 \mathrm{kkal}$, sedangkan kebutuhan responden lakilaki umur 12-15 tahun yaitu 2100-2475 kkal (Kementerian Kesehatan RI, 2014).

Asupan energi yang cukup menunjukan bahwa asupan atau konsumsi bahan makanan yang merupakan sumber tenaga pada responden sudah sesuai dengan kebutuhan harian, sedangkan untuk hasil energi yang masing kurang menunjukan bahwa konsumsi sumber tenaga tidak sesuai dengan kebutuhan harian dikarenakan jumlah porsi makanan yang dikonsumsi masih kurang (Adriani dan Wirjatmadi, 2012).

Hal ini sejalan dengan penelitian yang dilakukan Muchlisa (2013) pada Remaja Santri di Pondok Pesantren Yatim AT-THAYYIBAH Sukabumi proporsi asupan energi kurang sebanyak $60,5 \%$. Apabila asupan energi kurang dari kecukupan energi yang dibutuhkan maka cadangan energi yang terdapat didalam tubuh yang disimpan dalam otot akan digunakan. Kekurangan asupan energi berkelanjutan menyebabkan penurunan berat badan yang akan berdampak status gizi kurang berakibat terhambatnya proses pertumbuhan.

\section{Gambaran Tingkat Kecukupan Protein}

Sumber protein dalam jumlah atau porsi yang diajurkan dalam pedoman gizi seimbang responden usia 12-15 tahun yaitu sumber lauk hewani 2-3 porsi/hari dan lauk nabati 3 porsi/hari seperti daging ayam, ikan, telur, tempe dan tahu yang harus dikonsumsi responden.

Asupan protein yang tidak baik karena jumlah/porsi tidak sesuai dengan anjuran pedoman gizi seimbang. Kebutuhan konsumsi protein responden mengalami kenaikan sejalan dengan proses pertumbuhan yang pesat. Jadi jika konsumsi protein yang diperoleh dari makanan sesuai dengan angka kecukupan protein yang dianjurkan, maka proses tumbuh kembang akan berlangsung cepat (Almatsier, 2011).

Sejalan dengan penelitian Kusuma dkk (2014) selama masa responden, kebutuhan protein meningkat karena proses tumbuh kembang berlangsung cepat. Apabila konsumsi energi terbatas atau kurang, maka protein akan dipergunakan sebagai energi. Kebutuhan protein akan sangat penting pada kelompok responden karena protein ini terutama dibutuhkan untuk pembentukan jaringan baru atau untuk memperbaiki jaringan rusak. Protein sangat penting untuk responden karena pada masa ini terjadi laju pertumbuhan dan penurunan massa otot tubuh.

\section{Gambaran Status Gizi}

Status gizi tidak normal karena konsumsi makanan yang tidak sesuai dengan kebutuhan bisa berlebih ataupun kurangnya jumlah atau porsi makan, baik dalam jenis bahan makanan maupun frekuensi makan yang tidak baik dalam pemenuhan kebutuhan sehari-hari.

Status gizi responden tidak normal (malnutrisi) karena konsumsi makanan yang tidak baik dari porsi/jumlah dan frekuensi dalam pemenuhan kebutuhan sehari-hari. Kebutuhan untuk responden usia 12-15 tahun makanan pokok 4-61/2 porsi/hari, lauk hewani 2-3 porsi/hari, lauk nabati 3 porsi/hari, sayuran 3 porsi/hari, dan buah 4 porsi/hari. Status gizi ditentukan oleh kecukupan makanan dan kemampuan tubuh yang mengandung zat gizi untuk kesehatan.Keadaan gizi yang baik, tubuh mempunyai cukup kemampuan untuk 
mempertahankan diri terhadap penyakit infeksi (Soetjiningsih, 2010).

Sejalan dengan penelitian Musyayyib (2018) Keadaan gizi seseorang dapat berupa gizi kurang, gizi baik atau normal maupun gizi lebih. Bila kekurangan dalam batas marginal dapat menimbulkan gangguan yang sifatnya lebih ringan atau menurunkan kemampuan fungsional misalnya kekurang vitamin B1 dapat menyebabkan badan cepat merasa lelah. Kekurangan zat besi dapat menurunkan prestasi kerja dan prestasi belajar, selain turunnya daya tahan tubuh terhadap penyakit infeksi. Jika kecukupan konsumsi makanan berlebih akan mempengaruhi pertumbuhan dan mengakibatkan status gizi berlebih dan apabila berkelanjutan terus menerus dewasa akan memiliki resiko tinggi penyakit degeneratif.

\section{Hubungan Pola Makan dengan Status Gizi}

Pola makan yang baik mengandung makanan sumber energi, sumber zat pembangun dan zat pengatur, karena semua zat gizi diperlukan untuk pertumbuhan dan pemeliharaan tubuh serta perkembangan otak dan produktifitas kerja, serta dimakan dalam jumlah cukup sesuai dengan kebutuhan (Almatsier, 2011). Remaja dengan status gizi tidak normal memilik pola makan tidak baik dari salah satu jenis makanan, frekuensi dan jumlah makanan remaja belum mencukupi atau sesuai dengan ajuran pedoman gizi seimbang. Kebanyakan remaja tidak cukup jumlah atau porsi makanan dan jenis makanan yang belum beragam.Pola makan merupakan kesesuaian jumlah, jenis makanan dan frekuensi yang dikonsumsi setiap hari atau setiap kali makan oleh responden yang terdiri dari jenis makanan pokok, lauk pauk, sayur dan buah (Khairiyah, 2016).

Hasil penelitian ini sejalan dengan hasil penelitian (Musyayyib, 2018) tentang hubungan antara pola makan dengan status gizi pada remaja di Pondok Pesantren Nahdlatul Ulum Soreang Maros yang memiliki pola makan dan status gizi di peroleh nilai $p$-value $=0,01$ menunjukan, bahwa ada hubungan antara pola makan dengan status gizi remaja. Status gizi seseorang ditentukan berdasarkan asupan gizi dan kemampuan tubuh dalam menggunakan zat-zat gizi. Kebutuhan asupan yang berbeda akan mempengaruhi keadaan gizi seseorang.

Keadaan gizi dapat berupa gizi kurang, gizi baik atau normal maupun gizi lebih. Kekurangan salah satu zat gizi dapat menimbulkan konsekuensi berupa penyakit defisiensi. Bila kekurangan dalam batas marginal dapat menimbulkan gangguan yang sifatnya lebih ringan atau menurunkan kemampuan fungsional misalnya kekurang vitamin B1 dapat menyebabkan badan cepat merasa lelah. Kekurangan zat besi dapat menurunkan prestasi kerja dan prestasi belajar, selain turunnya daya tahan tubuh terhadap penyakit infeksi Jika kecukupan konsumsi makanan berlebih akan mempengaruhi pertumbuhan dan mengakibatkan status gizi berlebih dan apabila berkelanjutan terus menerus dewasa akan memiliki resiko tinggi penyakit degeneratif (Musyayyib, 2018).

Bahan makanan yang sering dikonsumsi remaja yaitu makanan cepat saji dikarenakan praktis, cepat disajikan dan mudah ditemukan disekolah, maupun diluar lingkungan sekolah. Konsumsi makan yang rendah kualitas maupun rendah gizi mengakibatkan kondisi atau keadaan gizi kurang. Konsumsi makanan dipengaruhi zat gizi dalam makanan, program pemberian makanan dalam keluarga, kebiasaan makan, pemeliharaan kesehatan, daya beli keluarga, lingkungan fisik dan sosial (Supariasa, 2012).

Sejalan dengan penelitian (Sa'diya, 2016) menunjukan bahwa p-value $(0,038)<(0,05)$ artinya ada hubungan antara pola makan dengan status gizi anak usia prasekolah di PAUD Tunas Mulia Desa Claket Kecamatan Pacet Kabupaten Mojokerto. Pola makan baik maupun buruk dipengaruhi oleh orang tua, pola makan yang baik pada responden dipengaruhi orang tua yang telah mengajarkan kebiasaan makan yang baik pada anak sejak kecil tentang kebiasaan makan yang baik sehingga dapat terbawa sampai mereka dewasa, sedangkan pola makan kurang baik karena orang tua tidak membudayakan disiplin makan pada anak, mereka cenderung menuruti kemauan anak tanpa memperhatikan nilai gizi yang anak mereka makan.

Penelitian juga dilakukan Noviani dkk (2016) Kebiasaan jajan dan pola makan serta hubungannya dengan status gizi anak usia sekolah di SD Sonosewu Bantul Yogyakarta. Hasil analisis Chi Square hubungan pola makan dengan status gizi diperoleh $p$-value 0,008 ( $p$ value $<0,05$ ) yang berarti bahwa ada hubungan antara pola makan dengan status gizi. Pola makan sangat mempengaruhi keadaan gizi seseorang. Pola makan yang baik dapat meningkatkan status gizi.Keadaan gizi kurang terjadi karena tubuh kekurangan satu atau beberapa jenis zat gizi yang dibutuhkan, sebaliknya untuk keadaan gizi lebih.

\section{Hubungan Tingkat Kecukupan Energi dengan Status Gizi}


Tingkat Kecukupan Energi yang dikonsumsi disesuaikan standar AKG 2013. Asupan energi yang cukup menunjukan bahwa konsumsi bahan makanan yang merupakan sumber tenaga atau energi pada remaja sudah sesuai dengan kebutuhan harian, sedangkan untuk asupan energi yang masing kurang menunjukan bahwa konsumsi sumber tenaga atau energi tidak sesuai dengan kebutuhan harian.Manusia membutuhkan energi untuk mempertahankan hidup, menunjang pertumbuhan dan melakukan aktivitas fisik. Energi diperoleh dari karbohidrat, lemak, dan protein yang ada di dalam bahan makanan.Kandungan karbohidrat, lemak, dan protein yang ada di dalam bahan makanan dalam menentukan nilai energi (Almatsier, 2009).

Remaja yang berstatus gizi tidak normal memiliki tingkat kecukupan energi tidak baik.Sementara remaja yang berstatus gizi normal memiliki tingkat kecukupan energi baik.Status gizi tidak normal disebabkan kebutuhan remaja masih belum sesuai dengan kebutuhan yang diajurkan dalam pedoman gizi seimbang. Kebutuhan energi yang dibutuhkan remaja perempuan 12-15 tahun yaitu 2000-2125 kkal, sedangkan kebutuhan remaja laki-laki umur 12-15 tahun yaitu 2100-2475 kkal. Jumlah yang tidak baik dan juga pola konsumsi yang salah seperti menu makanan yang tidak seimbang, kurangnya variasi makanan dan berlebih atau kuranganya frekuensi makan sehari dapat menyebabkan asupan energi tidak tercukupi ataupun berlebih dari kebutuhan sehari-hari, sehingga asupan energi akan berbeda-beda setiap remaja (Kementerian Kesehatan RI, 2014).

Sejalan dengan penelitian Rachmayani, dkk (2018) hasil uji antara asupan energi dan status gizi $(\mathrm{p}=0,001)$ dapat diketahui bahwa terdapat hubungan yang signifikan positif antara asupan energi dan status gizi. Hal ini menunjukan bahwa apabila terjadi peningkatan asupan energi makan akan terjadi peningkatan status gizi, dan sebaliknya. Konsumsi energi yang melebihi kecukupan dapat mengakibatkan kenaikan berat badan dan apabila terus berkelanjutan maka akan menyebabkan kegemukan dan resiko penyakit degenerative yang harus menjaga agar status gizi selalu dalam kondisi optimal.

Konsumsi makanan remaja tidak sesuai dengan kebutuhan remaja usia 12-15 tahun dalam pedoman gizi seimbang yaitu konsumsi jumlah atau porsi dengan sumber bahan makanan pokok 4-61/2 porsi/hari, lauk hewani 2-3 porsi/hari, lauk nabati 3 porsi/hari, sayuran 3 porsi/hari, dan buah 4 porsi/hari. Asupan makanan yang beranekaragam, frekuensi dan jumlah/porsi dapat mempengaruhi status gizi karena jumlah konsumsi sumber bahan makanan akan meningkatkan jumlah energi secara langsung.

Sesuai dengan hasil penelitian yang dilakukan (Efendi, dkk., 2016) Tingkat konsumsi energi yang berbeda, maka status gizinya akan berbeda. Bila konsumsi energi melalui makanan kurang dari energi yang dikeluarkan maka tubuh akan kekurangan energi. Sedangkan bila konsumsi energi yang diperoleh dari makanan melebihi energi yang dikeluarkan maka kelebihan energi tersebut akan disimpan dalam bentuk lemak tubuh, akibatnya terjadi berat badan yang melebihi berat badan idealnya dan akan semakin tinggi beresiko terjadi kegemukan.

\section{Hubungan Tingkat Kecukupan Protein dengan Status Gizi}

Hasil analisis ukuran asosiasi (OR) responden dengan kategori kecukupan protein tidak baik berpeluang 2,7 lebih besar memilik status gizi tidak normal dibandingkan dengan responden yang memiliki kecukupan protein baik.

Protein memiliki fungsi penting yang diperlukan tubuh diantaranya adalah untuk pertumbuhan dan pemeliharaan jaringan, sebagai salah satu penghasil utama energi, menurunkan bagian dari enzim dan antibodi, mengangkut zatzat gizi dari saluran cerna melalui dinding saluran cerna kedalam darah, dari darah menuju jaringan, kemudian melalui membran sel menuju sel, serta mengatur keseimbangan air (Sulistyoningsih, 2011). Selama masa remaja, kebutuhan protein meningkat karena proses tumbuh kembang berlangsung cepat (Adriani dan Wirjatmadi, 2014).

Remaja yang memiliki tingkat kecukupan protein tidak baik berstatus gizi tidak normal.Sementara remaja yang memiliki tingkat kecukupan protein baik berstatus gizi normal.Walaupun seluruh responden tetap atau selalu mengkonsumsi makanan sumber protein setiap hari, namun berdasarkan jumlah asupan masih banyak remaja yang dikategorikan tingkat kecukupan protein tidak baik. Kekurangan protein akan berdampak bagi laju pertumbuhan dan penurunan massa otot tubuh. Jadi jika konsumsi protein yang diperoleh dari makanan sesuai dengan angka kecukupan protein yang dianjurkan, maka proses tumbuh kembang akan berlangsung cepat (Almatsier, 2011).

Sejalan dengan penelitian (Kusuma, 2013) berdasarkan konsumsi protein, responden yang mengalami status gizi tidak normal $93,8 \%$ 
dengan konsumsi protein cukup. Kekurangan protein akan berdampak bagi pertumbuhan yang kurang baik, daya tahan tubuh menurun, lebih rentan terhadap penyakit, serta daya kreativitas dan daya kerja merosot. Asupan protein yang tidak baik dikarenkan konsumsi sumber protein yang tidak sesuai dengan kebutuhan berdasarkan hasil recall yang dilakukan. Fungsi protein antara lain kekebalan tubuh, pengganti jaringan yang rusak dan untuk pertumbuhan.

Proses pertumbuhan membutuhkan protein untuk membangun dan memelihara seluruh sel di dalam tubuh (More, 2014). Kebutuhan konsumsi protein pada usia remaja (10-12 tahun) mengalami kenaikan dengan porsi berdasarkan pedoman gizi seimbang yaitu lauk hewani 2-3 porsi/hari dan lauk nabati 3 porsi/hari seperti, daging ayam, telur ayam, ikan, tempe dan tahu dalam proses pertumbuhan yang pesat. Kebutuhan protein itu berbanding lurus dengan berat badan seseorang. Konsumsi protein yang diperoleh dari makanan itu memenuhi angka kecukupan protein yang dianjurkan, maka akan diperoleh status gizi yang baik (Almatsier, 2011).

Sejalan dengan penelitian Efendi, dkk., 2016) menunjukkan adanya hubungan yang bermakna antara tingkat konsumsi protein dengan status gizi pada remaja di SMP Negeri 2 Banjarbaru. Menunjukkan bahwa semakin baik tingkat konsumsi protein (TKP) maka semakin baik pula status gizi pada remaja tersebut. Penelitian ini juga dilakukan Rachmayani dkk (2018) hasil penelitian $p$-value $=0,027$ ada hubungan protein dan status gizi. Hal ini menunjukan bahwa bila terjadi kenaikan asupan makan akanterjadi peningkatan status gizi, dan sebaliknya.

\section{SIMPULAN}

Kesimpulan ada hubungan yang bermakna antara pola makan, tingkat kecukupan energi, dan tingkat kecukupan protein dengan status gizi remaja. Sebaiknya sekolah melakukan edukasi tentang pola makan yang baik dan porsi makan sesuai dengan pedoman gizi seimbang kepada Remaja SMP IT Iqra Kota Bengkulu agar status gizi normal meningkat.

Kementerian Kesehatan RI. (2018). Riset Kesehatan Dasar Tahun 2018. Jakarta: Balitbang Kemenkes RI.

Khairiyah, Evi Luthfiah. (2016). Pola makan Mahasiswa Fakultas Kedokteran dan Ilmu Kesehatan (FKIK) UIN Syarif Hidayatullah Jakarta 2016. [Skripsi]. Jakarta: Program Studi Kesehatan Masyarakat FKIK UIN Syarif Hidayatullah.

Kusuma, I.A, Saifuddin Sirajuddin, N. J. (2013). Gambaran Pola Makan dan Status Gizi Mahasiswa Program Studi Hasanuddin Makassar. [Skripsi]. Makassar: Universitas Hasanuddin.

More, Judy. 2014. Gizi bayi, Anak dan Remaja. Yogyakarta: Pustaka Pelajar.

Musyayyib, R., Hartono, R., \& Pakhri, A. (2018). Pengetahuan dan Pola Makan dengan Status Gizi Remaja di Pondok Pesantren Nahdlatul Ulum Soreang Maros. Media Kesehatan Politeknik Kesehatan Makassar, 12(2), 29-38.

Muchlisa. (2013). Hubungan Asupan Zat Gizi dengan Status Gizi pada Remaja Putri di fakultas kesehatan masyarakat universitas hasanudin Makassar tahun 2013. [Skripsi]. 
Makassar: Program studi ilmu gizi fakultas kesehatan masyarakat, Universitas Hasanudin Makassar.

Noviani, K., Afifah, E., \& Astiti, D. (2016). Kebiasaan jajan dan pola makan serta hubungannya dengan status gizi anak usia sekolah di SD Sonosewu Bantul Yogyakarta. Jurnal Gizi dan Dietetik Indonesia (Indonesian Journal of Nutrition and Dietetics), 4(2), 97-104.

Proverawati A, Asfuah S. (2009). Buku Ajar Gizi untuk Kebidanan. Yogyakarta: Nuha Medika.

Proverawati, A, Wati, E. K. (2011). Ilmu Gizi untuk Keperawatan \& Gizi Kesehatan.Yogyakarta: Nuha Medika.

Rachmayani, S. A., Kuswari, M., \& Melani, V.
(2018). Hubungan Asupan Zat Gizi dan Status Gizi Remaja Putri di SMK Ciawi Bogor. Indonesian Journal of Human Nutrition, 5(2), 125-130.

Sa'diya, L. K. (2016). Hubungan pola makan dengan status gizi anak pra sekolah di paud tunas mulia claket kecamatan pacet mojokerto. Jurnal

Kebidanan Midwiferia, 1(2), 69-78.

Soetjiningsih. (2010). Tumbuh Kembang Anak. Jakarta: EGC.

Sulistyoningsih, Hariyani. (2011). Gizi Untuk Kesehaan Ibu dan Anak. Yogyakarta: Graha Ilmu.

Supariasa, I. D. (2012). Penilaian Status Gizi. Jakarta: EGC. 